\title{
SOUTHEAST AsIa as a SOUTHEAST Asian FIELD OF STUDY ${ }^{1}$
}

\author{
O. W. Wolters
}

My first reaction to your kind invitation was a nervous one. I do not like to throw my weight around and did not feel that it was really my business to give advice to LIPI. But I had to admit to myself that I wanted to visit Indonesia again, and here I am but mourning the absence of two friends: my old traveling partner of Sriwijayan days, Yati Suleiman, and my old sparring partner also of Sriwijayan days, Boechari. Yet, when I began to ask myself questions about the meaning of the field of Southeast Asian studies as something more than the personal excitement of studying this or that about this or that part of the region, I once more became nervous.

The field, and area studies in general, emerged in the United States in 1948 with the explicit purpose of teaching Americans, many of whom were returning from Southeast Asia to civilian life, what they should know about a region of new nations whose affairs were beginning to impinge on their own at a time when the Cold War was getting under way. But recently, and more than forty years later, the report of a conference on Southeast Asian studies in the United States, the Wingspread Conference, was published under the disturbing title of Southeast Asian Studies in the Balance: Reflections from America. ${ }^{2}$ Does the title mean that these scholars were unsure of the identity of the field or was it simply a particular American reflection on how the field had developed in America? Indeed, one can go further and wonder for how much longer Southeast Asia will be regarded as an identifiable object for study. Perhaps the region we have been accustomed to refer to as "Southeast Asia" is already dissolving into other kinds of alignments such as the Asia Pacific Economic Cooper-

\footnotetext{
1 The article is an address, slightly modified, given on November 3,1993 to a conference, held in Jakarta, of Southeast Asian historians from the region itself and jointly organized by the Indonesian Institute of Sciences (Lembaga Ilmu Pengetahuan Indonesia, LIPI) and the Toyota Foundation. The conference's theme was "The Promotion of Southeast Asia Studies in Southeast Asia." I am grateful to Taufik Abdullah, chairman of the Steering Committee, for permitting me to publish the address in Indonesia. I would also like to thank A. Thomas Kirsch, Stanley J. O'Connor, and the late Lauriston Sharp, anthropologist, art historian, and anthropologist, respectively, for their valuable advice.

2 I am referring to a conference held at Wingspread, Racine, Wisconsin, in 1990. The report was edited by Charles Hirschman, Charles F. Keyes, and Karl Hutterer, Association for Asian Studies, 1992.
} 
ation Forum. Indeed, we have been given to understand that transnational influences are likely to transform the focus and issues of global and national affairs. ${ }^{3}$

Obviously, Southeast Asians are unlikely to feel the compelling need to learn about the societies and governments of Southeast Asia which Americans felt. Similarly, they are hardly likely to be seized by the sense of urgency with which Australians are approaching the field, a mood expressed in a recent report as a need to become "at ease with our geographical place in the world." How, then, can one attempt to state the case for Southeast Asian studies in Indonesia or, for that matter, elsewhere in Southeast Asia?

I suggest, for the purpose of discussion, that the major contribution of Southeast Asian studies within the region itself could be the enhancement of one's self-awareness in order to assist one in reaching a better understanding of the present. Perhaps, in an age of great change, there is more than ever a need for self-awareness: "Whence do we come? What are we? Where are we going?" Paul Gauguin exclaimed in 1897, though his intention, alas, was suicide. ${ }^{4}$ I shall go further and suggest, and again for the purpose of discussion, that LIPI might wish to involve itself in an informed critique of the present by undertaking what I shall refer to as a "watchdog" role by way of calling attention to history-oriented aspects of the field of Southeast Asian studies which may tend to be ignored. In this way LIPI could argue that the past, and therefore its study, might have a distinct and valuable bearing on what is happening today.

To this end I shall try to make a case for the relevance of Southeast Asian studies by calling attention to what I believe are some prominent cultural features or patterns associated with the region's past which, in my opinion, should not be neglected, and my listeners may then wish to ask themselves whether any of these features or patterns tend to be mirrored in the contemporary scene and, if so, with what consequences. ${ }^{5}$

What I shall say cannot help being only the views of one outsider, but I defend the salience of these features because I believe that they help to explain how people behaved in the past and how things happened. They would be influences which helped to shape the direction of Southeast Asian historical experience. My listeners may also ask themselves whether anything I shall say sheds light on the substance of "Southeast Asian civilization," something that those who contributed to the report of the Wingspread Conference found to be elusive.

These features or patterns - eight of them-were, I believe, widely shared throughout Southeast Asia. They were communalities, and the elite in this or that country could, if the occasion arose, understand each other. ${ }^{6}$ Today, too, perhaps they may help those living in

\footnotetext{
${ }^{3}$ David L. Fetherman, "What Does Society Need from Higher Education?" Items. Social Science Research Council, Volume 47, nos. 2/3, p. 38. The author is responding to Paul Kennedy's Preparing for the Twenty-First Century. 4 "D'où venons nous? Qui sommes nous? Où allons nous?" the title of his picture in the Museum of Fine Arts, Boston.

${ }^{5}$ For example, an Englishman, familiar with the history of nineteenth-century England and observing the contemporary scene in his own country, could be sensitive to signs of persisting class distinctions and anti-foreign sentiment. He might, too, have reservations concerning the long-term consequences of the Enlightenment, with its over-weeningly self-confident rationalism and its legacy of fascism and communism. He might also recognize more clearly the club-like atmosphere of party politics in the House of Commons. An American friend tells me that Americans today can recognize themselves in the pages of de Tocqueville.

${ }^{6}$ Tom Kirsch suggests that it is not improbable that Jayavarman II, coming, according to a Cambodian inscription, from "Java" to Cambodia, felt at home in either country. At least, the author of the inscription may have thought so.
} 
one part of the region go some way in understanding those living in another part of the region. I am not claiming that Southeast Asia had the monopoly of these features, and I am not identifying them with cultural values or attitudes of mind, though, of course, they would have generated values, a point to which I shall return. Above all, I am not proposing these common cultural features to the exclusion of cultural differences within the region, the study of which should surely be given the highest priority in any definition of Southeast Asian studies, provided that the case for the field in Southeast Asia itself has been made. The following eight cultural features represent my case for the field.

1 The first feature is that the only time that mattered was "now," the karma-fraught moment, for example, or the moment of spiritual enlightenment, or when an opportunity for earning worldly merit could occur. The past was pertinent only when it was believed to be clearly relevant to specific contemporary needs. The possibility of gradual progress was denied; instead, time was measured in terms of recurring cycles. The future held out no new possibilities.

And so it was that, during a conference a number of years ago, historians concluded that in the Southeast Asian tradition there was no interest in the past for its own sake. ${ }^{7}$ As one participant, a specialist on Thailand, put it, "the contemporaneity of the distant past is a hallmark of (indigenous) Southeast Asian historiography." 8 In the same tradition, a thirteenth-century Vietnamese historian could artfully quote ancient Chinese texts to counter Kublai Khan's claims to suzerainty, and in the fourteenth century a golden age in antiquity was invented to express nostalgia for a recent Vietnamese past. The past was the receptacle for myths and imagined times of prosperity. There would have been no sense of a linear past or notion that one should plan further ahead than, say, for the next campaigning season or for the next harvest. I hasten to observe that this should not be understood to mean cultural stagnation but, instead, a sense of achievement and even exultation when one could live at peace with oneself and one's environment.

2 Because "now" was the time that mattered, importance was attached to being up-todate or "contemporary": one should maximize one's opportunities for appropriating what were known to be useful skills appearing over the horizon by way of international trade routes or from within Southeast Asia itself.

The consequence of this opportunist and pragmatic attitude toward the present is seen in what historians used to refer to as "waves" of foreign influences which reached Southeast Asia first from India and later from the Middle East. New developments in India, for example, were soon registered in Southeast Asia. The great Indian philosopher, Sankara, who died about AD 750, is mentioned in a ninth-century Cambodian inscription. The signs of prompt movement of ideas across the Indian Ocean are manifold: successive Indian scripts and art styles, new texts-among which were the revised Theravāda texts of Sri Lanka from the eleventh century onward-and religious systems such as Tantricism or schools of Islamic mysticism and, later, calls for modernization from Islamic centers in the Middle East. Special means to special ends lie at the heart of Tantricism and would have been irresistable to empirically minded Southeast Asian rulers and their religious advisers.

7 Wang Gungwu, Perceptions of the Past in Southeast Asia (Singapore: Heinemann Educational Books [Asia]) Ltd, 1979), p. 4.

${ }^{8}$ Craig J. Reynolds, "Religious Historical Writing and the Legitimation of the First Bangkok Reign," in ibid., p. 103. 
The Southeast Asian elite's propensity to be au courant is to the historian's advantage because it encourages reflection on the conjuncture of events responsible for introducing new possibilities and enquiry about the nature and process of the changes which could then take place. In this way the past can be rendered in diachronic as well as in the synchronic terms suggested by the expression "cultural patterns."

Here is an illustration. The earliest known instance of what were once regarded as "waves" of foreign influence was the arrival in Southeast Asia of recently emerging schools of Hindu devotionalism in the first centuries of the Christian era. Cambodian inscriptions, which provide the earliest and reasonably ample materials on the subject, reveal that flamboyant Indian religious teachers, surely recognized by Khmers as exciting versions of their local "shamans" or whatever, were now becoming available to proclaim that supreme spiritual power could be attained here and now by means of simple and unbookish ascetic and meditative techniques which gave access to Siva's cosmic power (śakti) so that one could be hailed as Siva-like. Attaining something desirable here and now would be expected of any efficacious religious rite. The techniques-probably seen as of heroic proportions-were aimed at strengthening one's will-power and self-control, and the teachers' pupils were, first and foremost, the local chiefs. Thus, devotionalism and not Brahmanical rituals hit the epigraphic headlines, but it was not the popular devotionalism of southern India but a Southeast Asian elitist construction of its meaning and benefit to themselves. ${ }^{9}$

This episode, the details of which we owe to Cambodian epigraphy, suggests a paradigm applicable to the region as a whole in the form of a statement concerning what the present could offer and therefore why it was the present that mattered: the present could offer up-to-date skills and techniques which, if appropriated and mastered, would lead here and now to spiritual success and, no doubt, to all kinds of success.

3 The possibility of being "up-to-date" was often linked to and sustained by the sense of being an integral part of the whole of the known "world" rather than merely belonging to one's own patch of territory. The origin of this urbane, outward-looking, and global perspective, nourishing the elite's self-esteem, is, in my opinion, attributable to an ancient awareness among the elite that there was a "Hindu world," not an Indian one, which was an ever-to-be-updated world of Sanskrit books of canonical status in a sacred language which assumed that there were universally acceptable norms of behavior and shared symbols, images, and ideals, no matter what the local languages were. Here was a "cultural" community which spanned the whole region. To ignore it would be to remove perhaps a crucial element in early Southeast Asian historical experience. References to the great epic, the Mahäbhãrata-the window on the "Hindu world" and a limitless source of metaphors for the Southeast Asian elite-begin to appear in fifth-century inscriptions as far apart as southern Laos and eastern Kalimantan and are eloquent testimony to the "Hindu world's" span of scriptural authority.

The "Hindu world" was what we could now regard as an "imagined community." 10 It

\footnotetext{
${ }^{9}$ Indigenous texts could also be updated and to the historian's advantage. For example, the so-called Vietnamese folktales (the Việt-điện $\mathbf{u}$-linh tập) were adapted and therefore updated in the late fourteenth or in the fifteenth century to teach the need to discipline villagers. In this instance, the updating process reinforces what is already known about the elite's changing attitude toward the countryside.

10 Benedict Anderson, Imagined Communities (rev. ed., London: Verso, 1992), pp. 12-19 on "The Religious Community." The "Hindu World" is not included among communities defined in terms of a sacred language and written script.
} 
was no more than a selective appropriation and localization of materials, usually recorded in Sanskrit texts, to make local sense of and therefore familiar and valuable what was originally "foreign." Southeast Asians had the capacity to construe their own milieu and circumstances in terms of what they knew was recorded in Sanskrit literature as universal phenomena, and they would then proceed by a process of self-Hinduization to give "Hindu" names to themselves and to what they saw around them: for example, their mountains, rivers, sacred bathing pools, caves, stones, chiefs, overlords, and also those who did not belong to the elite groups in society. There was no limit to what could be described in "Hindu" language. Indeed, this world view required diversity. As my colleague Professor Kirsch has put it, in this process nature spirits could be "upgraded" to become part of the "Hindu" hierarchy and Siva "parochialized" to become the Creator of this or that region in Southeast Asia.

Indonesia was firmly in this universalist "Hindu world." As you know, Agastya is honored in the Prambanan. He is the sage of Tamil-nadu; to him Siva dictated the twenty-eight agama. And not far from the Prambanan in distance and time stands the Borobudur, a Mahāyāna Buddhist monument but assuredly of the "Hindu world," where Hinduism and the Mahāyāna never made exclusive claims on their followers but rather fed into each other. You will recall that the bas-relief of three of its galleries was identified by means of a Japanese recension as depicting passages from the Gandavyūha, a Mahāyāna text from perhaps southern India, translated into Chinese at the beginning of the fifth century and acclaimed in seventh-century China and eighth-century Japan. Here is further convincing evidence of the wide world within which a Southeast Asian people could effortlessly belong. ${ }^{11}$

The Vietnamese, too, belonged to the wide world or, rather, overlapping worlds. A thirteenth-century emperor, anxious to preach to his subjects the benefits of the meditation school of Buddhism, known in Japan as Zen, could extol without embarrassment the debt China and Vietnam owed the Indians who first propagated the Buddha's teachings across the deserts of Central Asia. But, again in Vietnam, Chinese classical writing about antiquity was held to reflect universal norms of experience and could be rhetorically invoked to ratify Vietnamese behavior. ${ }^{12}$ In the same mood, elsewhere in Southeast Asia the name of Kautilya, the Hindu master of statescraft, or of Manu, the lawgiver, could be invoked to validate local behavior as reflecting universal norms. And educated Vietnamese, familiar with and using such Chinese cultural artifacts as poetic forms or Chinese-style coinage or reign-periods, could enjoy the sensation of participating in the "civilized" world on equal terms with the Chinese.

In this "world" the center could be anywhere according to where one claimed it to be, which would be where one lived. There were innumerable centers. Professor Hendrik Maier observes that the Malay words for the compass points "tend to conceive the world from the perspective of their own community and plotted space relative to their ruler's (and their own) compound."13 Here is another instance of a genuine "world view," a basic element in

\footnotetext{
11 I am puzzled by the Cornell University Press's advertisement of the recently published Southeast Asia in the Early Modern Era. Trade, Power, and Belief, edited by Anthony Reid (Ithaca: Cornell University Press, 1993): "This book is the first to document . . the shift from experimental spirit worship to the universalist scriptural religions of Islam, Christianity, and Theravada Buddhism." I would think that nothing had been more magnificently "universalist" than "Hinduism."

12 Occasionally, but only rarely, Vietnamese rulers were urged by their advisers to be guided by ancient Chinese wisdom.

${ }^{13}$ H. M. J. Maier, "The Malays, the Waves, and the Java Sea," in Looking in Odd Mirrors: The Java Sea, ed. V. J. H. Houben et al. (Leiden: Vakgroep Talen en Culturen van Zuidoost-Asië en Oceanie, 1992), p. 12.
} 
the Southeast Asian cultural heritage. Part of the same heritage was hospitality toward those from elsewhere in that world and especially their bookish knowledge. Useful information and also foreigners with expert religious lore at their disposal traveled regularly over the trade routes from the most distant places.

4 What gave distinctive shape to public life within Southeast Asia itself was a cultural emphasis on "person" and "achievement" rather than on "group" and "hereditary" status. At the same time-and in contrast with South and East Asia, with their emphasis on ascribed status and collective units such as family, lineage, and caste-there was a downgrading of the importance of lineage based on claims to status through descent. Society had to be continuously monitored to spot potential leaders in a particular generation, and this outlook encouraged the habit of "present-mindedness." "Government" was not a matter of elaborate institutions but of a relaxed unbureaucratic style of public life, where importance was attached to man-management and ceremony and where personal qualities of leadership and example played the major role. I like the expression "relaxed" because it absolves one from having to beg the question of what is "strong" or "weak" government. Similarly, I prefer the neutral expression "polity" to "State." A relaxed style of public life did not mean that every polity was usually on the brink of collapse. One reason is the tradition that rulers and ruled depended on each other; the ruled could migrate if government suddenly became more severe. Interdependence would also be expressed when the villagers' shrines were protected by the ruler and, of course, when the ruler kept the peace in the countryside or repelled invaders.

In Vietnamese sources, too, mention is sometimes made of "extraordinarily" endowed persons who attracted followers. Vietnamese rulers, though believed to be protected by the spiritual authority of their family, were also attributed with possessing such special qualities as discernment in managing officials.

The crucial importance of the individual qua ruler could and usually was infinitely enhanced by the identification of his personal prowess with the divine attributes of a cosmic god of the "Hindu" pantheon or of a local spirit or, indeed, of both. "Hinduization" had been a process of making sense of what was "foreign" in terms of what was already familiar, and so it was that the attributes of Siva could be construed as those of the local man of prowess. Thus, the ruler was "god-like" and associated with the sources of fertility and therefore of life itself. There was a pervasive apprehension of the supernatural forces of the land and water. According to Vietnamese popular belief, he who deserved to rule would apprehend the presence of a local spirit and thereby win its allegiance and invincible support. The spirits were always at hand to be summoned, and this perception, too, reinforced the conviction that "now," the time of apprehending, was the time that mattered.

There was bound to be competition between contending men of prowess; there was no room at the top for more than one person. While the amount of prowess in the world was limitless and could be shared, authority and power were limited in amount. When a person's prowess had been satisfactorily tested, the successful competitor's authority and power would be absolute and could not be shared or transmitted.

A leader with discernibly superior prowess was associated with the capacity to attract followers, who were anxious to earn a meritorious reputation, personal advancement in the leader's service, and a share of the leader's wealth, though the same followers would switch their allegiance when their leader could no longer protect them. Rulers would provide impressive public occasions when their followers could advertise their relative status. Earning 
merit by serving a leader with divine attributes in order to stand oneself in good stead after death could also be a significant motive in public life. Relations with one's peers within an entourage could be uneasy. This, at least, was Vietnamese experience, where a ruler's followers tended to compete against each other for his favors.

Apart from the prestige of the hermitage and the priesthood, nothing rivaled that of public life. ${ }^{14}$ Response to an established leader would be automatic, and processes of social mobilization would be set in train. Leadership could be exercised in various ways; a recent study of the Minangkabau polity in the seventeenth century indicates that receipt of the ruler's written word could be expected to transform the situation even in distant places. ${ }^{15}$

The leader-led relationship may have put a brake on the extension of wider human collectivities. There were cults of kingship rather than "kingdoms"; a "kingdom" was the geographical projection of a leader's prowess. The institutions of entourage, dependency-in various forms-and alliance thrived in the shadow of this kind of leadership because these institutions contributed to what a leader most needed, which was ample manpower resources. The experience of belonging to entourages might have helped to foster a tendency to seek consensus, a cultural feature reflected in the context of current ASEAN diplomacy. 16 But this is unlikely. "Consensus" is associated with the composing of ideological differences. An "entourage" can be more properly described as a set of personal loyalties animating a group of followers, each of whose loyalty was directed to his leader. In general, ties were personal rather than based on an abstract notion of "loyalty." Behavior would be informal except during ceremonial occasions; the followers' roles could change when circumstances required. The entourage had, of course, to be rallied before an adventure could be undertaken. "Rallying" was one of the dynamic happenings in the region. An entourage need not have been large. With about 600 men whom he had rallied in a small river valley, Datu Uto in the nineteenth century turned Magindanao upside down.

Here is a famous example of an entourage in Javanese history. After the "disaster" (the pralaya) in the eleventh century, Erlangga escaped with "the best of his servants," his faithful entourage. His cause gradually snowballed. He was always victorious, but he distributed the booty among his "servants" and "took away only the glory for himself" (meaning, I take it, the verification of his prowess).

There was no widespread "corruption" in the sense of hoarding wealth for personal ends. Instead, there was an imaginative redistribution of wealth in the form of gracious favors. There were patrons and clients. Generosity, creating a sense of obligation, was a required royal virtue. Loyalties had to be continually replenished by rewards in bad as well as good times.

\footnotetext{
14 In a major study of early Southeast Asian coinage, Robert Wicks has established the validity of Philip Grierson's model: "it was only after a physical money, such as a standardized coinage, came to be accepted for use in making administrative payments that money was able to be utilized in commercial (marketized) exchange"; Robert S. Wicks, Money, Markets, and Trade in Early Southeast Asia (Ithaca: Cornell Southeast Asia Program, 1992), p. 312. In other words, public administration and not private trade first brought this facility into being.

15 Jane Drakard, "A Kingdom of Words: Minangkabau Sovereignty in Sumatran History" (Ph.D. thesis, The Australian National University, 1993). A captured letter from Amangkurat II, Susuhunan of Mataram, in connection with his receipt of Raja Sakti's letter, states that he bowed "reverently before the great Sultan of Minangkabau since we share the Islamic faith"; ibid., p. 242.

16 On ASEAN (Association of Southeast Asian Nations) diplomacy, see Pushpa Thambipillai, "Negotiating Styles," The ASEAN Reader, compiled by K. S. Sandhu et al. (Singapore: Institute of Southeast Asian Studies, 1992), pp. 72-75.
} 
Successful warfare was, of course, a sign of a proven leader, even though military campaigns rarely led to permanent political solutions and never to large-scale colonization. Leaders needed the maximum space in which to flex their muscles. Warfare did not change the map except at the expense of Vietnam's southern neighbors during the few short-lived intervals of strong dynastic government in Vietnam. One did not have to belong to a ruler's ethnic group to be his subject. The ethnic patchwork of Southeast Asia was sometimes accentuated by the movement of captives and their resettlement in a conqueror's heartland.

The institutions of entourage and alliance, nourished by largesse available from trading treasure, were probably especially important influences among those societies, such as the Javanese, which practiced bilateral kinship and where extensive followings could be readily built up on both sides of one's family.

What Anthony Reid has referred to as the high degree of "autonomy of women" should be regarded as a cultural feature in its own right, but in my present context of entourage and alliance I shall do no more than endorse, if I may, what he has to say about "descent," which "was (usually) reckoned bilaterally in terms of the status of both father and mother, which provided one element of uncertainty about succession." 17 I doubt whether sufficient emphasis can be given to the institution of bilateral kinship, especially when one takes the practice of multiple marriages into account. Here we are in the presence of a veritable reservoir of potential claimants to kingship and of a source of political instability; there were few more dangerous persons in Southeast Asia than half-brothers or brothers-in-law. Such was the entrenched social status of Southeast Asian women that in Vietnam before the nineteenth century, and in spite of the authority of Chinese legal codes, protection was guaranteed to "the right of daughters to equal inheritance of the portion of family estate remaining after disposition of the worship property." 18 Furthermore, women enjoyed the legal protection of some personal rights such as the right to sue husbands for neglect. ${ }^{19}$

5 In this achievement-oriented culture, manpower was a leader's chief economic resource and was especially necessary for providing a surplus agricultural product to support the Court, public works, military adventures, and overseas trade. Rulers would be expected to prevent disasters, protect religious works, and be accessible to the people by providing mediators when disputes arose. One may suppose that nowhere should authority have been more valued than in village communities, where the inhabitants could pursue their agricultural activities without interference from powerful families in the neighborhood, though I have been given to understand that Thai and Burman villagers would view their rulers as one of the intrinsic "disasters" they faced and comparable with natural disasters such as flood and drought.

An uninterrupted arrival of trading treasure, regarded as the ruler's right, was assumed. A contributor to Southeast Asia in the Early Modern Era has rightly stated that "the importance of appropriating a commercial resource base for establishing political power cannot be overestimated in the Southeast Asian context." 20 Another historian has remarked that

17 Anthony Reid, Southeast Asia in the Age of Commerce, 1450-1680. Vol. 1: The Lands below the Winds (New Haven: Yale University Press, 1988), p. 120.

${ }^{18}$ Nguyễn Ngọc Huy and Tạ Văn Tài ...., The Lê Code. Law in Traditional Vietnam, vol. 1 (Athens: Ohio University Press, 1989), p. 80.

${ }^{19}$ Ibid., pp. 81-82.

${ }^{20}$ Jeyamalar Kathirithamby-Wells, "Restraints on the Development of Merchant Capitalism in Southeast Asia before c. 1800," Southeast Asia in the Early Modern Era, ed. Reid, p. 129. 
"Malays, it would seem, sought wealth not for its own sake but as a means of gaining political influence in the form of a sizeable personal following."21 There has always been an age of commerce in Southeast Asia even if the levels, conditions of exchange, and sources of economic stimulus were not the same over the centuries. A notable feature of a recent conference on the Java Sea is that Malay and Javanese literature, though referring to the sea, was found to be virtually silent on matters of trade; overseas trade could be taken for granted. ${ }^{22}$

I have referred to an "outward-lookingness" in earlier Southeast Asia which promoted the sense of belonging to a wide world. The same trait could serve local concerns. The structure of Indonesian written and oral sources has suggested to a maritime historian that the origins of "kingdoms" on the coasts of the Java Sea were associated with the success of local heroes in manipulating the arrival of foreign trading treasure to their advantage. ${ }^{23}$

6 Not surprising in this cultural context, leaders were idealized and even venerated as teachers of good behavior, usually conceptualized as good religious behavior. The qualities expected of worthy rulers could comprise all or some of the following according to the degree with which the qualities were respected in a particular society: courage, ascetic selfcontrol, physical strength, resourcefulness, rhetorical skill, discernment, accessibility, compassion, willingness to protect the rights of others, an ability to mediate, generosity, and especially skill in managing and mobilizing networks of personal relationships. The ruler, partaking of divinity, was expected to be the exemplar of all that was deemed good, beautiful, and true.

Monuments, visual aids to worship and reminders of the rulers' ubiquitous presence, bore witness to the rulers' stature as well as to their successful control and manipulation of resources. The inscriptions relayed religious messages, and art made the great Hindu epics and the Buddhist canon visible and therefore accessible. These are the texts, to which the shadow puppet plays belonged, which shaped behavior and taught Southeast Asian societies what could and should be the quality of an individual's life. These were the texts which defined the ideal ruler. ${ }^{24}$

7 But in spite of the high expectations of kingship, there were no prolonged or, probably, any periods of strong "centralized" government. Although a ruler's authority could be seen as absolute, this was on account of his God-like attributes and not his administrative powers. Siva could be the Creator of the Universe without having to supervise it in every detail. The ruler's day-to-day power was based on the norms in his society. A political system cohered only in the sense that it was a projection of a leader's personal influence,

21 A. C. Milner, Kerajaan. Malay Political Culture on the Eve of Colonial Rule (Tucson, Arizona: University of Arizona Press, 1982), p. 27. Robert Wicks observes that "in early Southeast Asia internal trading activities were frequently supervised in order to limit the amount of surplus that could be accumulated by traders and merchants"; Money, Markets, and Trade, p. 310. Or again, "foreign goods more often appear in the context of status enhancement, supporting an argument that inter-cultural trade was most often carried on, not to accumulate surplus for its own sake, but for the political, social, and religious benefits that could accrue from control over exotic and unusual goods"; ibid., pp. 312-13.

22 Houben et al., Looking in Odd Mirrors: the Java Sea.

23 Pierre-Yves Manguin, "The Merchant and the King: Political Myths of Southeast Asian Coastal Polities," Indonesia 52 (October 1991): 41-54.

${ }^{24}$ I am grateful for Stanley J. O'Connor's guidance. 
backed by the personal loyalty and ubiquity of the leader's representatives. Only short-term goals were plausible.

And so it was that regimes were not long lasting, a circumstance consistent with the principle of cyclical time. ${ }^{25}$ Even in Vietnam effective "dynastic" government was always short-lived, though the Chinese-style imperial institution had been localized in the tenth century to suit Vietnamese needs. ${ }^{26}$ Ngô Sĩ Liên, a Vietnamese historian of the later fifteenth century, reviewed what had happened under the previous dynasty in the thirteenth and fourteenth centuries and deplored what he regarded as signs of instability such as dependence on entourages, obsessive merit-seeking, and personal and informal relations at Court. We would recognize these features as being "Southeast Asian" without judging them to be defects. ${ }^{27}$ Only Vietnamese historians made a fetish of the need for strong government because they knew that it rarely existed. Their "imperial" institution should have offered the promise of strong government in what they imagined was China's style, yet they knew that it was always being corroded. The fifteenth-century historian, Ngô Sĩ Liên, was, in my opinion, nervous about the future because of what he regarded as endemic institutional and cultural weaknesses revealed in the recent past.

8 Because of relaxed governmental institutions, ethnic identities on the edges of the major polities were left undisturbed and often represented by contiguous ecological layers on the physical map. There were no "borders" in the modern sense but only porous peripheries. The region was "Balkanized" but without ethnic-grounded "Balkan" wrath. Populations might be transferred after a war or there might be raiding for slaves. Otherwise, ecological factors kept ethnic groups in habitation zones where they could live comfortably. There were, of course, vital economic interdependencies such as upstream and downstream, forest and agricultural peoples, forest collectors, and port polities. In some areas there was a considerable degree of bi-lingualism and opportunities for manipulating one's identity. Bilingualism signifies that people with different origins had learnt to live together. ${ }^{28}$

Yet peripheries were indispensable to the center's status. A ruler's prestige depended on his claim to be the overlord of a multi-ethnic polity. ${ }^{29}$ Moreover, overlordship, though often no more than ceremonial, was a form of self-defense because the rival overlord would be deprived of the services of those who lived in the porous borderland. What lay beyond the porous borders was always a matter of concern to an overlord, and one consequence would

25 According to Claude Jacques, "From the inscriptions it emerges clearly enough that regional rebellions were seldom absent in the Angkorian period, and the Royal Chronicles, not to speak of some present-day reports, tell of many such rebellions against the central power. I am sure it would not be going too far to say that they have been endemic in the Khmer land from the very beginning of history"; "Sources on Economic Activities in Khmer and Cham Lands," in Southeast Asia in the 9th to 14th Centuries, ed. David G. Marr and A. C. Milner (Singapore: Institute of Southeast Asian Studies, Singapore, 1986), pp. 229-30.

26 Primarily to protect the succession to the throne within a particular family. One consequence of the weakness of the Vietnamese dynastic institution was its frequent dependence on right-hand men, usually known as thai-uiy, instead of on an entrenched bureaucracy to assist young or weak rulers. These "protectors," as they were called, were liable to usurp when the chance occurred, and, for this reason, the Trần dynasty in the thirteenth and fourteenth centuries appointed their closest kinsmen as thái-úy.

27 I discussed this matter in an article in Sojourners and Other Settlers: Histories of Southeast Asia and the Chinese, in Honor of Jennifer Cushman, ed. Anthony Reid (Sydney: Allen and Unwin, forthcoming): "What Else May Ngô Sĩ Liên, a Fifteenth Century Vietnamese Historian, Mean? A Matter of Distinctions."

28 During the conference in Jakarta considerable attention was given to the need to study how those living in pluralistic societies managed to fit in together. Here could be a further cultural feature of the region.

29 For example, in the Lao and Perak courts leaders of the hill peoples were accorded status and titles. 
be the importance attached to up-to-date and accurate political intelligence in order to monitor developments in neighboring territories. I suggest that the skills of diplomacy are part of the Southeast Asian tradition.

An exception to this situation is provided by the Vietnamese, who were able gradually to extend their southern borders at the expense of the Chams. Yet as late as the fourteenth century, discontented Vietnamese were prepared to seek refuge over the southern border in Champa, and an edict was issued to forbid Vietnamese from adopting foreign speech and clothes. And in the nineteenth century the Hû́e emperors complained that some Vietnamese villagers in the south were becoming "Khmer" in speech and clothing.

So much for some proposed "cultural features." 30 The first three are associated with the notion of "now": "now" is the time that matters in all fields of useful knowledge; the sense of belonging to a wide world would multiply the opportunities for being up-to-date. The other five features are similarly related to the notion of "now": "now" is when one identifies among one's generation an up-and-coming man of prowess, who will need and attract manpower and trading revenue and will be venerated, though his political influence will be no more than a projection of his personal prowess and will not be territorially defined.

Few, if any, of these features are peculiar to Southeast Asia. ${ }^{31}$ Perhaps the importance of "person" and "achievement," a relaxed exercise of power, extreme multicentricism, and unusual geographical access to the outside world, though no doubt non-Southeast Asian examples can be adduced, are more pronounced in the region than in many other parts of the world. On the other hand, the combination of these features-their configuration-may be distinctively Southeast Asian, with the effect that each feature would reinforce the others. For example, I noted that the habit of spotting potential leaders in a particular generation would encourage the habit of "present-mindedness."

The conclusion would therefore seem to be that Southeast Asian experience in the past had always been a matter of endless "nows." I have, in effect, made a case for Southeast Asia's remarkable propensity for being "modern." Furthermore, the benefits to be gained from being "modern" are today obviously overwhelming. For example, in April this year The Economist had a supplement on Indonesia, and its title was "Wealth in its Grasp." 32 It would not be surprising if some should suppose that the influence of the past was a retarding one and that tradition was a drag on progress and the benefits of modernity.

I must now remind you that I have proposed these cultural features with the hope that they may stimulate self-awareness among a Southeast Asian audience. It is not my purpose to impose my views on you. You may reject what I have suggested as being historically implausible. Or you may acknowledge some of these features in a modified form but suggest additional and more important ones. But, whatever the case, I hope that the question will be whether today any feature of the past is still visible on a significant scale or, at least,

\footnotetext{
${ }^{30}$ For a succinct formulation of prehistoric and persisting Southeast Asian "cultural inlays," see Lauriston Sharp, "Cultural Continuities and Discontinuities in Southeast Asia," The Journal of Asian Studies 22, 1 (1962): 9, n. 9.

${ }^{31}$ For example, as Benedict Anderson puts it, "... the mediaeval Christian mind had no conception of history as an endless chain of cause and effect or of radical separations between past and present." Imagined Communities, $p$. 23. He goes on to quote Auerbach: "the here and now is no longer a mere link in an earthly chain of events, it is simultaneously something which has always been, and will be fulfilled in the future." See n. 8 above for a comment on a similar Southeast Asian approach to time.

32 "A Survey of Indonesia. Wealth in Its Grasp," The Economist, April 17, 1993.
} 
whether tendencies or even inclinations can be detected which resemble what $I$ have been trying to describe. Has there been a fundamental change in form or is it only a matter of paraphernalia or technology? Alternatively, have entirely new patterns of life and new types of public figures come to occupy the stage? Above all, is there anything in the pastfeatures or merely tendencies-which can be regarded as a resource or impediment in this present age?

I can at last return to the notion of LIPI as a "watchdog." If a lively sense of the past does not happen to be a Southeast Asian cultural feature and if, as I have suggested, such a sense would stimulate self-awareness and therefore a critique of the cultural background to what is happening at the present time, LIPI could respond by taking the initiative and arguing that an indifference to past experience could compromise the way one manages the present on behalf of the future. LIPI would demonstrate how historians possess their own insights into the contemporary situation.

LIPI could first examine and criticize the assumptions and perspectives reflected in my sketch of the past and, where necessary, come up with different sketches of what may be salient in the sense of explaining how people behaved and how things happened. LIPI could then make the essential point that these cultural features could have generated a core of shared values or attitudes of mind, prejudices against as well as for certain modes of behavior, which persist even today. For example, a present-focused attitude toward time and a tradition of hospitality toward ideas and individuals from the outside world are still surely forces to be taken into account. The Southeast Asian experience of a widely open world suggests that multinational corporations and anything else that can be labeled "cosmopolitan" readily fits into this aspect of the cultural tradition. And what about the notion that wealth is less valuable for its own sake than as a source of political power? And would a tendency to think in terms of what the present has to offer engender consumer habits?

LIPI might then choose to insist that persisting values need not be repudiated wholesale in a frenzy of self-modernization. Instead, they should be scrutinized, judged, asserted, or kept under tight control in the light of priorities created by the extraordinary circumstances of the modern world and by future goals. Instead of a frenzy of modernization, one could calmly and critically assess the strengths and weaknesses of the cultural heritage still visible in its traces today, and consider which values would be a resource and which would be otherwise. Here might be a means of mobilizing the past to guide or even manipulate one's response to changed conditions in the world. ${ }^{33}$

If, however, there were to be no such scrutiny and reordering of inherited values, what would the future be? Would there be an endlessly recurrent influence of the same cultural features or tendencies? Would there be a state of involution which would not give enlightened modernism its chance? To take the worst prospect, perhaps the configuration of

\footnotetext{
${ }^{33}$ Here are two examples of a positive approach to the past, present, and future. A Cambodian teacher, able only recently to resume her vocation, states that she has decided that her calling is "to help my country, the future of my country" by dancing and teaching. She is an educator but of a special kind: she is concerned to "re-educate" her fellow countrymen so that they may recover what in the past had been smothered by the Khmer Rouge; Toni Shapiro, "Dancing in Cambodia," Southeast Asia Program Bulletin (Cornell University), Spring 1993, pp. 2-3. A Javanese artist provides an example of how one can emulate behavior patterns of earlier times to replenish contemporary life. She has in mind the practice of meditation and everything associated with it, such as the sensation of being in harmony with nature. "People forget where they come from," she says. "There is a need for self-awareness in the present age of endless competition so that one may overcome a sense of inferiority. One needs to ask oneself what are the achievements of the past-always cultural ones-in order to challenge and maybe bring order to the present"; personal communication from Hilda Soemantri Siddhartha.
} 
Southeast Asia in the past would have already prefigured the postmodern condition, in which progress would be neither thinkable nor achievable.

But only Southeast Asian historians would be able to pounce on those inherited values which could contribute to goals set for the future or hinder the management of necessary changes. Only they may know whether a traditional focus on the present may encourage improvidence in respect of the future. Only they may know whether more prestige still accrues to those in government service than to those, for example, who work in the private sector and whether it matters. Only they may know whether the traditional respect paid to the individual who achieves and attracts an entourage represents an appropriate standard of leadership in the modern age. Is the institution of the entourage more or less prominent today? And only they may be able to evaluate the influences that work in favor of a less relaxed style of government. ${ }^{34}$

I am not qualified to comment on such matters. They are for the scholars of the areas, as also are three more questions. Is there anything in the modern world which seems to make particular sense and is therefore familiar in terms of what was already there, and, if so, what confidence can this provide? "Hinduization," I suggested, should be understood as a "Hinduizing" process which depended essentially on a Southeast Asian capacity for making sense of what was "foreign" and unfamiliar in terms of what was already familiar. ${ }^{35}$ Is modernization being construed in a similar way and, if not, why not? The second matter is whether an intensive study of the past would encourage regional centricisms at the expense of a supra-regional nation and, at the same time, demolish pleasing historical myths.

Finally, LIPI may wish to examine from the perspective of cultural history a recent World Bank report, The East Asian Miracle. How much in the report, when read between the

34 I have read Southeast Asian Capitalists, ed. Ruth McVey (Ithaca: Cornell Southeast Asia Program, 1992). Dr McVey's introductory essay ("The Materialization of the Southeast Asian Entrepreneur") covers a great deal of ground I had ignored and especially the shifting relationship of bureaucrats and businessmen. She evinces a measured optimism about the prospects awaiting Southeast Asian capitalists. Yet much of what she writes makes sense to a historian of earlier Southeast Asia and, above all,what she has to say about the attraction of "modern" skills and the influence of the international environment, though I wonder whether a MBA would be sufficient to smother one's traditional cultural attitudes when reaching middle age. Can one identify a man of prowess in the business world? He might be someone adept at man-management as distinct from technical skills and one who was entirely at home in the international business and professional society in general. I believe that Ruth McVey has this kind of society in mind when she refers on p. 32 to "the interplay of complex interests ... which will be expressed more and more through agencies, associations, and lobbies rather than through the dyadic relationships of patron-client networks." The modern man of prowess would build up his entourage by developing relationships with potential partners, by organizing mergers - maybe by marriages-and by acquiring subsidiaries. Here would be contemporary scope for the traditional aptitude for building alliances.

35 Ruth McVey's second option below is obviously congenial to me. Studying the Taman Siswa, she supposes: "Some, conscious of lost time and fearful the country might never catch up to modernity's receding image, might urge that the most modern ideas and methods must be imposed; others might feel that anything that was itself very modern in style was less likely to have a modernizing effect on the society than something less radically different from the society's own experience"; Ruth T. McVey, "Taman Siswa and the Indonesian National Awakening," Indonesia 4 (October 1967): 135. It would be interesting to bring together discussions of the meaning of modernity. According to Jurgen Habermas, "Modernity revolts against the normalizing functions of tradition; modernity lives on the experience of rebelling against all that is normative. This revolt is one way to neutralize the standards of both morality and utility." See his "Modernity Versus Post Modernity," in Postmodern Perspectives: Issues in Contemporary Art, ed. Howard Risatti (Eaglewood Cliffs, New Jersey, Prentice Hall, 1990), p. 56. I am grateful to Stanley O'Connor for the reference. Habermas also points out that modernity is something which is itself always doomed to be outmoded. Rudolf Mrázek has suggested to me that being self-consciously or even fashionably "modern" could reflect personal insecurity, a sense of being uprooted to the extent that one felt obliged to denounce the past. 
lines and freed from the language of economists, is predictable to a cultural historian? How far does its description of contemporary economic developments mirror cultural features in the region's past? Indonesia, Thailand, Malaysia, and Singapore comprise the report's four Southeast Asian "superstars." To what extent are value systems inherited from the past responsible for this economic situation?

I am sure that many more questions can be raised on these lines. All I have tried to do is to suggest that, within Southeast Asia itself, there may be practical as well as academic reasons for studying the Southeast Asian past and reviewing its legacy in terms of appropriate attitudes of mind in the context of confronting the modern world. LIPI may wish to foster a public opinion favorable to this proposition. ${ }^{36}$

May I suggest one further responsibility for LIPI which is to consider how the Southeast Asian past may be profitably studied to make it intellectually exciting as well as relevant?

In my opening remarks I referred to the Wingspread report on Southeast Asian studies in the United States. LIPI might wish to respond to certain passages in it. For example, the author of the epilogue referred to "the perception that Southeast Asian studies may lack both a coherent intellectual foundation and a compelling practical rationale for mobilizing the public and private resources needed to sustain and expand its academic practice. ${ }^{237} \mathrm{He}$ also stated that "we must define the core of our field by seeking to understand the essence of Southeast Asian civilization. This means that we must refocus our efforts on the study of the literatures, religions, and the arts of the region in their historical development and contemporary contexts. .. . I have no doubt," he went on to say, "that such studies will find common themes underlaying the Southeast Asian social and cultural mosaic, themes that define the essence of Southeast Asian civilization." 38 I wonder whether one explanation of the Wingspread Conference's hand-wringing mood may be that participants looked wistfully backward rather than forward. Surely the civilizations of Southeast Asia are being created today and tomorrow; the contribution of the past is to enable us to establish valuable continuities or needed breaks.

I suggest, therefore, and I hope not mischievously, that LIPI may wish to respond to Wingspread's impression of the impoverished state of the field and the phantom-like nature of Southeast Asian "civilization."

The effectiveness of LIPI's response to these reservations of their colleagues overseas would be closely connected with the question of "how" to study the past: the disciplines involved and their relationships. There is always a need to create an interest in the field by innovative and challenging research. Southeast Asian studies must be lively; after all, they are an arena for interdisciplinary work and, for this reason, the field may have enviable prospects. The experience of interdisciplinary activity can foster a tendency to build bridges with additional disciplines in order, if I may quote something I have read recently, "to expand the technical repertoire and conceptual boundaries." ${ }^{39}$ As a result, entirely new prob-

\footnotetext{
36 On p. 13 of Culture and Society in New Order Indonesia, ed. Virginia Matheson Hooker (Kuala Lumpur: Oxford University Press, 1993), Hooker notes that one "theme which runs through the essays is that traditions which survive have done so in new contexts." The cultural features explored in the present essay are behavioral patterns rather than artistic forms. Moreover, the question is less whether they are capable of surviving than whether they should.

37 Southeast Asian Studies, p. 135.

38 Ibid., p. 141.

${ }^{39}$ Featherman, "What Does Society Need," p. 40.
} 
lems can be identified and the educational merits of the field thereby safeguarded. Ideally speaking, the field should be perpetually renewing itself, and part of LIPI's role could be to call attention to what is exciting about the region and methodologies deployed in its study.

The "watchdog" may also wish to argue the case for the purposes and contributions of certain disciplines in the humanities. Which are the particularly creative disciplines at the moment ${ }^{40}$ I wish to make a special plea for anthropology, the study of the arts and archaeology, and literary studies, because I believe that these are disciplines likely to bring one close to the heartbeat of "Southeast Asian civilization" or, more accurately, the heartbeats of the various civilizations of Southeast Asia, for regional communality in respect of certain cultural patterns cannot possibly mean that cultural differences did not and do not exist among these societies.

The case for anthropology and the study of the arts and archaeology hardly needs to be made here. Both fields are well established in Southeast Asia. Anthropology studies how things in societies happen, whereas historians may sometimes tend to be content with what happened and why. One way of stating the contribution of art history is that it concerns itself with the realm of appearance, where people once lived and where they could define and recognize themselves. Art history deals with self-awareness in the past, and selfawareness is the central theme of my remarks today. Art history, in the words of an art historian, "offers ways of reconnecting perception and imagination, the circuit of cognitions, which these works once ignited and through which their meanings were established." 41

I would, however, like to say a few words on behalf of literary studies within the context of Southeast Asian regional studies. Several Wingspread participants stressed the importance of studying literature.

What I have in mind by "literary studies" is the study of literature for its own sake: "how" a piece of writing is "made" in the sense that its "text" is an artifact comprising structures and the linguistic usages conventional in a particular culture. Here we can get closer to a text's "voice," and here is an opportunity for exploring the notion that Southeast Asia comprises numerous cultures, each leaving its special mark on a local literature. ${ }^{42}$ Exposure to the discipline of textual study, the essence of this approach to literary studies,

\footnotetext{
40 One contributor to the Wingspread report, the only historian, made a powerful case for the history of religions in order "to establish an effective humanistic beachhead within Southeast Asian studies"; Southeast Asian Studies, p. 64, n. 11.

41 I am again grateful to Professor O'Connor.

42 I tried to fly this kite in my History, Culture, and Region in Southeast Asian Perspectives (Singapore: Institute of Southeast Asian Studies, 1982). My intention was not to preclude the study of "early regionalized networking as the basis for the more meaningful study of administrative structure and for political, religious, and commercial development ...," though Kenneth Hall, in a review of Robert Wicks's Money, Markets, and Trade in Early Southeast Asia, regrets that my influence has discouraged such a study; The Journal of Asian Studies 52, 3 (1993): 803-4. I am sufficiently familiar with art history to realize that this would be foolish. My point was simply that one should not take it for granted that the unit we recognize as "Southeast Asia" was always conveniently intact and familiar so that historians could go ahead and explore with confidence "the cultural and economic integration" to which Hall refers and evidently prefers to study. As I put it in 1982, "Until more is known in historical terms of this singular feature of Southeast Asia (its cultural diversity), the search for an overarching shape to the region's history will lack a satisfactory basis" (Southeast Asian Perspectives, pp. 45-46). Needless to say, I accept Keith Taylor's article of faith which Hall sorrowfully quotes in his review. But I did not box myself in. I was aware of the phenomenon of cultural relocalization within the region, and this prevents too restricted a sense of locality. I also conceded that there was a wide span of peoples with concurrent modes of behavior and with communalities of outlook. My paper today is an extended discussion of such communalities.
} 
can sharpen curiosity and alertness when one is investigating the presence of connections, relationships, differences, disruptures, and instabilities mirrored in literature and also in the web of social and political happenings. Textual study can enlarge a scholar's sensitivity and especially to the use of language within a culture. ${ }^{43}$

I am sure that literary studies, anthropology, and the study of the arts would go some way in responding to the Wingspread Conference's perplexity about the nature of Southeast Asian civilization and therefore about the substance of "Southeast Asian studies." One participant referred to "our efforts to convince our humanities oriented colleagues in other fields that Southeast Asian civilizations and cultures are, in fact, worthy of focussed attention." 44 I prefer to consider one's expectations of literary studies by referring again to what I suggested were pronounced cultural features in Southeast Asia. If what I have said has any validity, it would be to an important extent because it is reflected in literary sources, defined in the widest meaning of the term. But the special contribution of literature and also of the arts and anthropology must be to bring to light so much more that is interesting about the region's independent cultural heritage and without the needless obligation of having to make the case for "Southeast Asian civilizations."

The influence of LIPI's role as I have presumed to define it would not be limited to Indonesia or Southeast Asia. LIPI would have the obligation of communicating westwards scholarly perspectives gathered from within Southeast Asia. My final point, therefore, is that LIPI might wish to respond to the Wingspread Conference's hope that a greater exchange of ideas between Western and Southeast Asian scholars would invigorate the field. Few developments would be more enlivening than the beaming of Southeast Asian scholarly perspectives beyond the region. We, at the western end of the academic spectrum, would learn from having our concerns scrutinized and evaluated from a vantage point we could never occupy.

In the past I have unsuccessfully urged that Southeast Asian historians of Southeast Asia should hold a modestly priced conference somewhere in Southeast Asia, be locked up in order, undisturbed, to discuss matters of concern to each of them, and then consider, among other things, whether they could produce their own joint History of Southeast Asia. ${ }^{45}$ The possibility would now arise of a seminar to prepare a new history of Southeast Asia and one which was not simply a stringing together of National Histories but would be informed by regional self-awareness and values as well as being professionally acceptable. And perhaps the same seminar could explore the possibility of a comparative study of modernizing Southeast Asian countries in historical perspective.

This morning I have suggested that a sense of the past should stimulate self-awareness and that historians could possess their own and valuable critical insights in respect of what they saw happening around them. With these suggestions in mind, I would like to conclude by recalling the words of a famous nineteenth-century Englishman, the future Cardinal Newman, who, in The Idea of a University, ascribes many noble qualities to the educated

43 For example, Rudolf Mrázek's regret that a recent and valuable translation of Tan Malaka's From Jail to Jail suppressed the "strangeness" of his language which played a crucial role in his appeal; Rudolf Mrázek, "Tan Malaka: Just as Artisans, When Gathered Together,'" Indonesia 53 (April 1992): 67.

44 Southeast Asian Studies, p. 62.

45 A comparative study of how Southeast Asian scholars have rendered Southeast Asian National Histories and cultural identities would be a singular contribution to the field. 
intellect. Among these qualities is one which Javanese historians not too long ago and, I am confident, LIPI's historians today and surely all in this room would affirm. Such an intellect, writes Newman, "is almost prophetic from its knowledge of history." 46

Thank you.

3 November, 1993

46 Owen Chadwick, Newman (rep. Oxford: Oxford University Press, 1990), p. 55; Nancy K. Florida, "Writing the Past, Inscribing the Future: Exile and Prophecy in an Historical Text of Nineteenth-Century Java," 2 vols. (Ph.D. dissertation, Cornell University, 1990), vol. 2, chap. 8 (Conclusion: History and Prophecy). 
